\title{
Cryptic speciation of the zoogonid digenean Diphterostomum flavum n. sp. demonstrated by morphological and molecular data
}

\author{
Carmen Gilardoni ${ }^{1}{ }^{*}$, Jorge Etchegoin ${ }^{2}$, Thomas $\mathrm{Cribb}^{3}$, Susana Pina ${ }^{4}$, Pedro Rodrigues ${ }^{4,5}$, María Emilia Diez ${ }^{1}$,
} and Florencia Cremonte ${ }^{1}$

${ }^{1}$ Laboratorio de Parasitología, Instituto de Biología de Organismos Marinos (CCT CONICET-CENPAT), Boulevard Brown 2915, U9120ACF Puerto Madryn, Argentina

2 Laboratorio de Parasitología, IIPROSAM - Instituto de Investigaciones en Producción Sanidad y Ambiente, FCEyN, Universidad Nacional de Mar del Plata - CONICET, Juan B. Justo 2550, 7600 Mar del Plata, Argentina

3 School of Biological Sciences, The University of Queensland, Brisbane, 4072 Queensland, Australia

${ }^{4}$ Laboratorio de Sanidade, ICBAS - Instituto de Ciencias Biomédicas Abel Salazar, Universidade do Porto, R. Jorge de Viterbo Ferreira 228, 4050-313 Porto, Portugal

${ }^{5}$ Laboratorio de Imunidade Inata e Ferro, I3S - Instituto de Investigação e Inovação em Saúde, Universidade do Porto, R. Alfredo Allen, 4200-135 Porto, Portugal

Received 30 December 2019, Accepted 23 May 2020, Published online 18 June 2020

\begin{abstract}
Diphterostomum brusinae (Zoogonidae) is a digenean species that has been recorded worldwide parasitizing marine fishes. Several species have been synonymized with $D$. brusinae because they lack conspicuous morphological differences. However, due to the breadth of its geographic distribution and the variety of hosts involved in the life cycles, it is likely to be an assemblage of cryptic species. Diphterostomum flavum n. sp. is described here as a morphologically cryptic relative of $D$. brusinae, in the fish Pinguipes brasilianus (Pinguipedidae) off the Patagonian coast, Southwestern Atlantic Ocean, and its life cycle is elucidated through morphology and molecular analysis. This species uses the gastropod Buccinanops deformis (Nassariidae) as first and second intermediate host with metacercariae encysting within sporocysts. They also, however, use the polychaete Kinbergonuphis dorsalis (Onuphidae) as second intermediate host. No morphological differences were found between adults of D. flavum n. sp. and D. brusinae; however, the number of penetration glands of the cercariae, a diagnostic feature, differed ( 9 vs. 3 pairs), as well as the ITS2 sequences for the two species. This work provides morphological and molecular evidence of cryptic diversification among species described as D. brusinae, in which the only clear differences are in larval morphology and host spectrum. The strict specificity to the snail acting as the first intermediate host and the variety of fishes with different feeding habits acting as definitive hosts support the likely existence of multiple cryptic species around the world.
\end{abstract}

Key words: Life cycle, Zoogonidae, Pinguipes brasilianus, Cryptic species, Patagonian coast.

Résumé - Spéciation cryptique du Digène Zoogonidae Diphterostomum flavum n. sp. démontrée par des données morphologiques et moléculaires. Diphterostomum brusinae (Zoogonidae) est une espèce de digène, parasite des poissons marins, qui a été signalée dans le monde entier. Plusieurs espèces ont été synonymisées avec $D$. brusinae parce qu'elles ne montrent pas de différences morphologiques visibles. Cependant, en raison de l'étendue de sa répartition géographique et de la variété d'hôtes impliqués dans les cycles de vie, il est probable qu'il s'agisse d'un assemblage d'espèces cryptiques. Diphterostomum flavum n. sp. est décrit ici comme une espèce morphologiquement cryptique de D. brusinae, chez le poisson Pinguipes brasilianus (Pinguipedidae) au large de la côte de la Patagonie, dans le sud-ouest de l'océan Atlantique, et son cycle de vie est élucidé par la morphologie et l'analyse moléculaire. Cette espèce utilise le gastéropode Buccinanops deformis (Nassariidae) comme premier et deuxième hôte intermédiaire avec des métacercaires s'enkystant dans les sporocystes. Cependant, elle utilise également le polychète Kinbergonuphis dorsalis (Onuphidae) comme deuxième hôte intermédiaire. Aucune différence morphologique n'a été trouvée entre les adultes de $D$. flavum n. sp. et D. brusinae, mais le nombre de glandes de pénétration des cercaires, une caractéristique diagnostique, diffère (9 paires contre 3), ainsi que les séquences ITS2 pour les deux espèces. Ce travail fournit des preuves morphologiques et moléculaires de la

\footnotetext{
*Corresponding author: gilardoni@cenpat-conicet.gov. ar
} 
diversification cryptique parmi les espèces décrites comme $D$. brusinae, dans lesquelles les seules différences claires sont dans la morphologie des larves et le spectre de l'hôte. La spécificité stricte au mollusque servant de premier hôte intermédiaire et la variété de poissons avec différentes habitudes alimentaires servant d'hôtes définitifs soutiennent l'existence probable de plusieurs espèces cryptiques dans le monde.

\section{Introduction}

Cryptic speciation has been reported to be common among parasites. Due to a limited range of morphological features among parasite taxa, many species exhibit similar or identical morphology; however, they may differ in host-parasite interactions [45]. Cryptic species are typically discovered through molecular genetics, behavioral, or ecological studies of diversity $[19,42]$. Using molecular data, cryptic diversity has been detected extensively in trematodes species [19, 29, 33, 44]. Digenean species with homogeneous morphology but infecting a wide range of host species are candidates for complexes of cryptic species [29, 37, 46]. This may be the case for Diphterostomum brusinae (Stossich 1888), a zoogonid trematode parasitizing the intestine of fish, which has been recorded in North and South America, Europe, Asia, and Oceania (Fig. 1). Molecular data for this species and related genera are scarce; only the sequences of ribosomal DNA (18S and ITS1) for D. brusinae from North of Portugal are available [26, 60].

The life cycle of $D$. brusinae has been elucidated from the Mediterranean Sea [54, 55], Black Sea [21], and the Atlantic coast of Portugal [26, 60] (Fig. 2). In all these studies, gastropods are the first intermediate hosts and metacercariae were found encysting inside the sporocysts. Metacercariae can also develop outside the sporocysts. The list of second intermediate hosts includes gastropods, bivalves and other sedentary invertebrates, such as the crinoid Antedon mediterranea [62]. Occasionally, the metacercariae encyst on the surface of algae and aquatic plants [21].

In Argentina, Timi et al. [77] and Gilardoni et al. [31] reported the adult of $D$. brusinae in the Brazilian sandperch Pinguipes brasilianus Cuvier (Pinguipedidae), from the coasts of Buenos Aires Province, San Matias Gulf, and Nuevo Gulf (Patagonia). Later, Martorelli et al. [43] reported it from the Whitemouth croaker, Micropogonias furnieri (Desmarest) (Sciaenidae), from the Bahía Blanca estuary and Samborombón Bay (Buenos Aires province). With respect to intra-molluscan stages, sporocysts (containing cercariae and/or metacercariae) of a Diphterostomum species were found parasitizing the intertidal snail Buccinanops deformis (Kiener) (Nassariidae) in Nuevo Gulf [31], and in Samborombón Bay [43].

Here we described D. flavum n. sp. from Pinguipes brasilianus from off the Patagonian coast, Argentina, elucidated its life cycle, and identified it as a cryptic species of D. brusinae using morphological and molecular data.

\section{Materials and methods}

\section{Data collection and parasite study}

Intra-molluscan stages (sporocysts, cercariae, and intrasporocyst metacercariae) of Diphterostomum sp. were previously described by Gilardoni et al. [31] from the gastropod Buccinanops deformis from the intertidal and shallow subtidal regions of Punta Cuevas ( $42^{\circ} 46^{\prime}$ S, 645' ${ }^{\prime}$ W), Puerto Madryn, Chubut Province, Argentina. To improve the prevalence data, $B$. deformis were sampled from two additional intertidal sites (Table 1). Gastropods were dissected alive and the presence of parasite (sporocysts) was recorded.

To locate the second intermediate hosts of the cycle, the most common macroinvertebrates that cohabit with the molluscan host (B. deformis) were examined (Table 1). Among these invertebrates, metacercariae belonging to the family Zoogonidae were found only in the polychaete Kinbergonuphis dorsalis (Ehlers) (Onuphidae), collected from the sandy sediment using a shovel and a 1-mm mesh. In the laboratory, 72 specimens of $K$. dorsalis were flattened between a slide and a coverslip, and examined for parasites under a light microscope. In addition, 13 specimens of Pinguipes brasilianus Cuvier (Pinguipedidae), obtained through spear-fishing from three sites (Table 1), were freshly examined for adult stages of Diphterostomum. To this end, stomach and intestines of $P$. brasilianus were removed and examined under a light microscope. Both metacercariae and adults were studied in vivo using both neutral red and Nile blue stained and unstained specimens. Flukes were killed with heated seawater and were immediately fixed with $10 \%$ buffered formalin, preserved in $70 \%$ ethanol and stained with Semichon's acetocarmine or Gomori's trichrome. After being cleared with methyl salicylate, the adults were mounted in Canada balsam and measured. Descriptions of the encysted and excysted metacercariae and adult were based on several live and fixed and stained specimens $(n=15)$. Drawings were made with the aid of a camera lucida, and the measurements are given in micrometers $(\mu \mathrm{m})$, followed by the range in parentheses. Some of the fixed specimens were dehydrated and dried by rinsing for a few minutes in hexamethyldisilane. The adults were then gold-coated for observation; the samples were photographed using a JEOL JSM-6460LV scanning electron microscope (SEM).

A total of 24 sporocysts, 10 metacercariae, and 19 adults were stored in $96 \%$ ethanol for molecular studies. Prevalence of sporocysts, metacercariae and adults and mean intensity of metacercariae and adults were calculated according to Bush et al. [12] (Table 1). Metacercariae from $K$. dorsalis and adults from $P$. brasilianus were deposited at the Parasitological Collection, IBIOMAR, CCT CONICET Centro Nacional Patagónico (CNP-Par 75, 76), Puerto Madryn, Argentina. All the scientific names are used according to WoRMS [79].

Samples of $B$. deformis $(n=143)$ from Cracker Bay (42 $51^{\prime} 33^{\prime \prime}$ S, 644ㄴ $16^{\prime \prime}$ W), Nuevo Gulf, Chubut Province, Argentina, was transported live to the laboratory and placed in small flasks filled with seawater at room temperature $\left(20-23{ }^{\circ} \mathrm{C}\right)$. The gastropods were inspected twice daily under a stereomicroscope for emerged cercariae. Experimental infections were performed by placing a large number of emerged cercariae in small containers with target hosts (four polychaetes Platynereis sp. (Nereididae), 20 non-native recent invader 


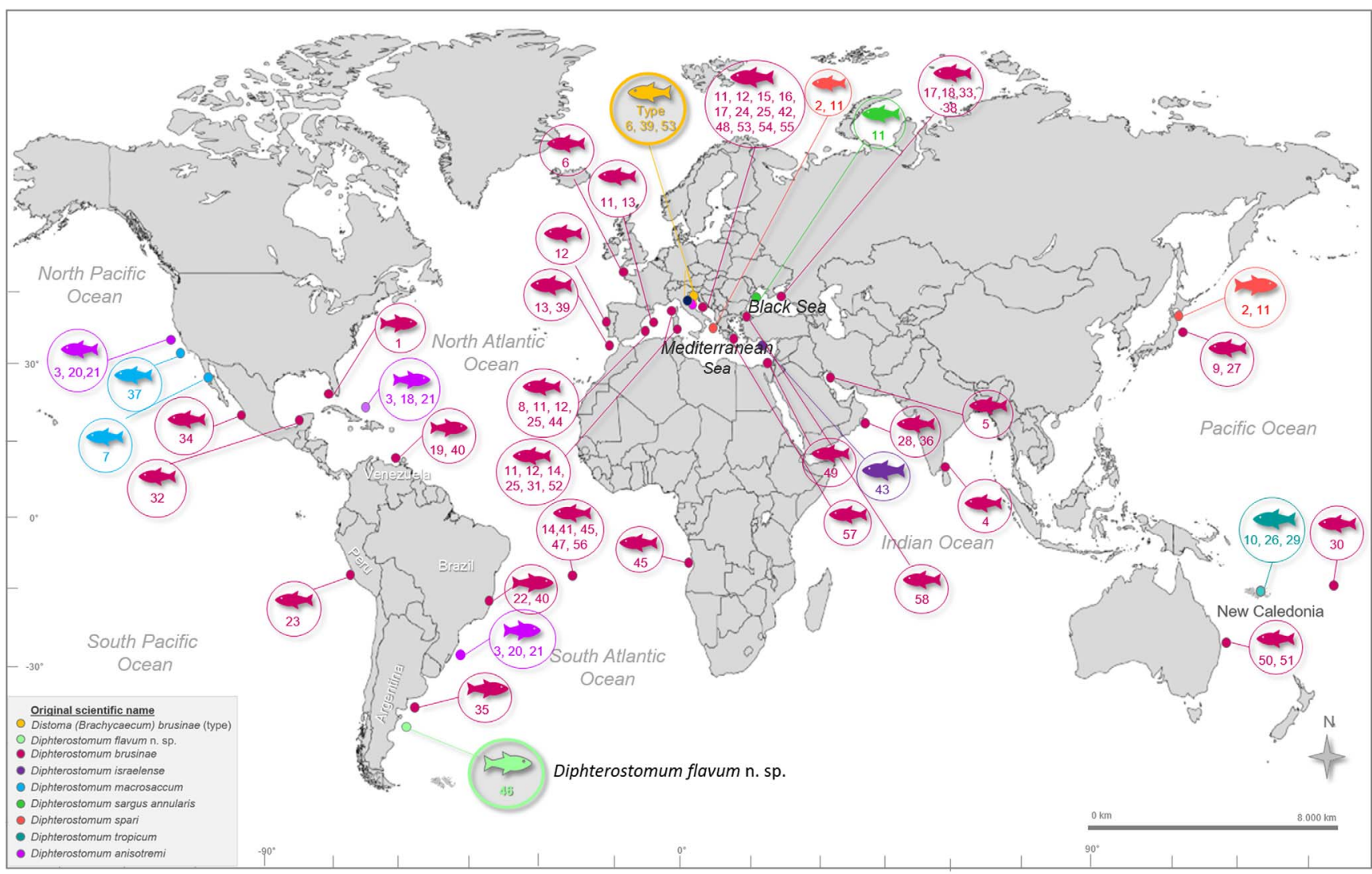

Fish definitive host

1-Acanthostracion quadricornis (Ostraciidae) [49]

2- Acanthopagrus berda

(Sparidae) [82]

21- Haemulon sciurus

22- Haemulon steindachneri

3- Anisotremus virginicus

(Haemulidae) $[4,48]$

23- Isacia conceptionis

24- Labrus bergylta

5- Argyrops spinifer

6- Blennius ocellaris

(Sparidae) [57]

25- Labrus merula

(Blenniidae) [11,72]

26- Lethrinus glyphodon

(Malacanthidae) [59]

27- Lethrinus haematopterus

7- Caulolatilus affinis

8- Coris julis

(Labridae) $[7,47,66]$

28- Lethrinus nebulosus

9- Cheilodactylus zonatus

10- Chrysophrys aurutus

11- Diplodus annularis

12-Diplodus sargus

Cheilodactylidae) [41]

29- Lethrinus sp.

(Sparidae) [35]

30- Lethrinus obsoletus

(Sparidae) $[5,8,63,64,82] \quad 31$ - Lithognatus mormyrus

(Sparidae) $[5,8,60,63,64]$

32- Mayaheros urophalmus

3- Diplodus sp.

(Sparidae) [40]

33- Mesogobius batrachoceph

14- Diplodus vulgaris

15- Gobius bucchichi

16- Gobius cruentatus

17- Gobius niger

(Sparidae) $[5,27,63,64]$

34- Microlepidotus brevipinnis

35- Micropogonias furnieri

36- Nemipterus japonicus

(Gobiidae) [67]

37- Neoclinus uninotatus

38- Neogobius melanostromus

18- Gobius ophiocephalus

(Gobiidae) $[51,54,67]$

Gobiidae) [51]

39- Oblada melanura

40- Orthopristis ruber

(Haemulidae) $[4,48]$ (Haemulidae) [34,48]

(Haemulidae) [34]

(Labridae) $[39,47]$

(Labridae) $[7,13,14,39,47,66]$

(Lethrinidae) [24]

(Lethrinidae) [80]

(Lethrinidae) [57]

(Lethrinidae) [24]

(Lethrinidae) [50]

(Sparidae) [5]

(Cichlidae) [59]

(Haemulidae) [59]

(Sciaenidae) [43]

(Chaenopsidae) [81]

(Gobiidae) [51]

(Sparidae) $[11,40]$

(Haemulidae) $[34,48]$
41- Pagellus acarne

42- Pagellus bogaraveo

43- Pagellus erythrinus

44- Parablennius gattorugine

45- Parapristipoma octolineatum

46- Pinguipes brasilianus

47- Podamasys jubelini

48- Sarpa salpa

49- Saurida undosquamis

50- Sillago analis

51- Sillago maculata

52- Sparus aurata

53- Symphodus cinereus

54- Symphodus roissali

55- Symphodus tinca

56- Umbrina canariensis

57- Umbrina cirrosa

58- Zosterisessor ophiocephalus
(Sparidae) [27]

Sparidae) [67]

(Sparidae) [65]

(Blennidae) $[7,66]$

Haemulidae) [27]

(Pinguipedidae)

(Haemulidae) $[3,27]$

(Sparidae) [67]

Synodontidae) [27]

(Sillaginidae) [11]

(Sillaginidae) [11]

Sparidae) $[5,11]$

(Labridae) [39,47]

(Labridae) $[39,47]$

(Labridae) $[39,47,63,64]$

(Sciaenidae) [27]

(Sciaenidae) [56]

(Gobiidae) [53]

Figure 1. Geographical distribution of species described as Diphterostomum brusinae (Stossich, 1888) (Digenea, Zoogonidae) from fish around the world. References for each record are given between brackets.

Boccardia proboscidea Hartman (Spionidae), and 20 clams Ardeamya petitiana (d'Orbigny) (Tellinidae). Target hosts were collected from Puerto Madryn, where the search for metacercariae had proven negative (Table 1). The target hosts were examined between a slide and a coverslip at the light microscope for parasites nine days post-exposure. Metacercariae found were measured and compared with naturally obtained metacercariae from $K$. dorsalis through a non-parametric Kruskal-Wallis test [70]. Overall prevalences and mean intensity between experimentally and naturally infected metacercariae were compared through a Logistic and Poisson Regression, respectively [16].

\section{Molecular analyses}

DNA from sporocysts from $B$. deformis, metacercariae from $K$. dorsalis, adults from the intestine of $P$. brasilianus, and metacercariae of $D$. brusinae from Cerastoderma edule (Linnaeus) (Cardiidae) were extracted using a Sigma-Aldrich GenElute Mammalian Genomic DNA kit (St. Louis, MO, USA). Polymerase chain reaction (PCR) amplifications were performed in a total volume of $50 \mu \mathrm{L}$ with an amplification profile consisting of 40 cycles of $30 \mathrm{~s}$ at $94{ }^{\circ} \mathrm{C}, 30 \mathrm{~s}$ at $54{ }^{\circ} \mathrm{C}, 120 \mathrm{~s}$ at $72{ }^{\circ} \mathrm{C}$, followed by $10 \mathrm{~min}$ at $72{ }^{\circ} \mathrm{C}$ for the final 

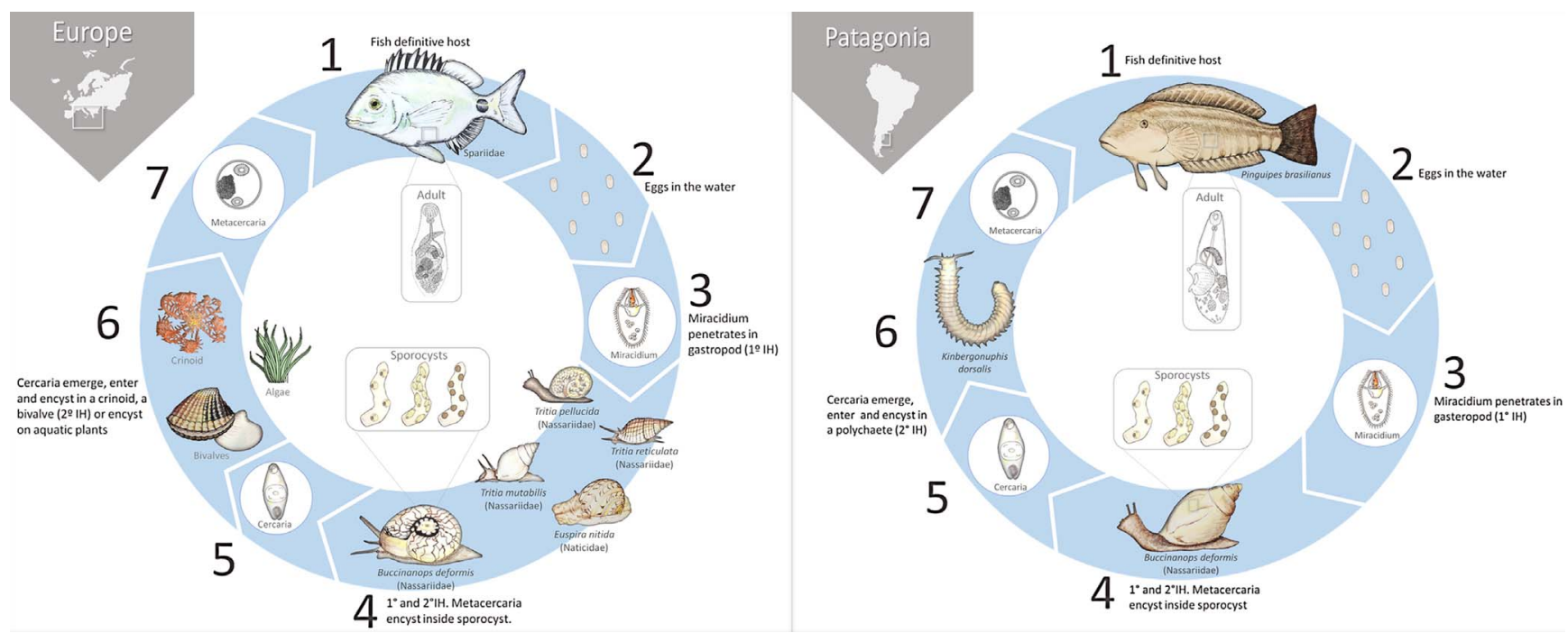

Figure 2. Schematic diagram of the known life cycles of the digenetic zoogonids Diphterostomum brusinae from Europe and Diphterostomum flavum n. sp. from Patagonia (South America). Abbreviations: IH, intermediate host. References: [21, 25, 54, 55, 60, 62].

Table 1. List of invertebrates and fish dissected for developmental stages of Diphterostomum flavum n. sp. from the Patagonian coast,



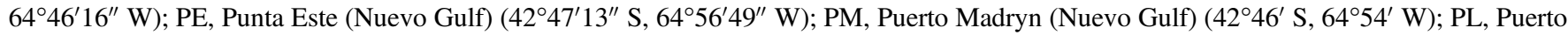
Lobos (San Matías Gulf) (41 $\left.58^{\prime} 50^{\prime \prime} \mathrm{S}, 65^{\circ} 04^{\prime} 05^{\prime \prime} \mathrm{W}\right)$.

\begin{tabular}{|c|c|c|c|c|c|c|c|}
\hline Host examined & Locality & $\begin{array}{l}\text { Collection } \\
\text { date }\end{array}$ & $\begin{array}{c}\mathrm{N} \\
\text { examined }\end{array}$ & $\begin{array}{l}\text { Prevalence } \\
\quad(\%)\end{array}$ & $\begin{array}{c}\text { Mean } \\
\text { intensity }\end{array}$ & Stages & $\begin{array}{l}\text { Infection } \\
\text { site }\end{array}$ \\
\hline \multirow[t]{2}{*}{ Buccinanops deformis King (Gastropoda: Nassariidae) } & FB & $\begin{array}{l}\text { May-Jan } \\
2011\end{array}$ & 430 (I) & 3 & nd & $\begin{array}{c}\text { Sp, C, } \\
\text { M }\end{array}$ & G, DG \\
\hline & $\mathrm{CB}$ & Jan 2014 & $143(\mathrm{I})$ & 13 & nd & $\begin{array}{l}\text { Sp, C } \\
\text { M }\end{array}$ & G, DG \\
\hline $\begin{array}{l}\text { Kinbergonuphis dorsalis (Ehlers) (Polychaeta: } \\
\text { Onuphidae) }\end{array}$ & $\mathrm{CB}$ & Jan 2014 & 72 (I) & 22 & $2(1-3)$ & M & $\mathrm{Mu}$ \\
\hline \multirow[t]{2}{*}{ Ardeamya petitiana (d'Orbigny) (Bivalvia: Tellinidae) } & PM & Oct 2013 & $\begin{array}{l}50(\mathrm{I}) \\
13(\mathrm{~S})\end{array}$ & - & - & - & - \\
\hline & $\mathrm{CB}$ & Jan 2014 & $30(\mathrm{~S})$ & & & & \\
\hline Ovalipes trimaculatus (De Haan) (Decapoda: Ovalipidae) & $\mathrm{PM}$ & Oct 2013 & $6(\mathrm{~S})$ & - & - & - & - \\
\hline Boccardia proboscidea Hartman (Polychaeta: Spionidae) & $\mathrm{PM}$ & $2010-2013$ & 2666 (I) & - & - & - & - \\
\hline Dipolydora cf. flava (Claparède) (Polychaeta: Spionidae) & $\mathrm{PM}$ & 2010-2013 & $226(\mathrm{I})$ & - & - & - & - \\
\hline Spio quadrisetosa Blake (Polychaeta: Spionidae) & PM & 2010-2013 & $30(\mathrm{I})$ & - & - & - & - \\
\hline Rhynchospio glutaea (Ehlers) (Polychaeta: Spionidae) & PM & 2010-2013 & 25 (I) & - & - & - & - \\
\hline Boccardiella ligerica Ferronnière (Polychaeta: Spionidae) & PM & 2010-2013 & $5(\mathrm{I})$ & - & - & - & - \\
\hline Clymenella sp. (Polychaeta: Maldanidae) & PM & 2010-2013 & $50(\mathrm{I})$ & - & - & - & - \\
\hline Cirratulus sp. (Polychaeta: Cirratulidae) & PM & $2010-2013$ & $10(\mathrm{I})$ & - & - & - & - \\
\hline Halosydna patagonica Kinberg (Polychaeta: Polynoidae) & PM & $2010-2013$ & $5(\mathrm{I})$ & - & - & - & - \\
\hline Platynereis sp. (Polychaeta: Nereididae) & PM & 2010-2013 & $25(\mathrm{I})$ & - & - & - & - \\
\hline Glycera sp. (Polychaeta: Glyceridae) & $\mathrm{CB}$ & Jan 2014 & $6(\mathrm{I})$ & - & - & - & - \\
\hline \multirow{3}{*}{$\begin{array}{l}\text { Pinguipes brasilianus Cuvier (Actinopterygii, } \\
\text { Pinguipedidae) }\end{array}$} & PL & Nov 2012 & $6(\mathrm{~S})$ & 33 & $14(3-21)$ & A & In \\
\hline & $\mathrm{CB}$ & Mar 2013 & $3(\mathrm{~S})$ & 33 & 19 & $\mathrm{~A}$ & In \\
\hline & $\mathrm{PE}$ & Feb 2014 & $4(\mathrm{~S})$ & 25 & 4 & A & In \\
\hline
\end{tabular}

Abbreviations: I, intertidal; S, subtidal; Sp, sporocyst; C, cercaria; M, metacercariae; A, adult; G, gonad; DG, digestive gland; Mu, muscle; In, intestine; nd, non determined.

extension. The ITS2 region of the rDNA was amplified using a digenean specific primer located at 114 base pairs (bp) from the $3^{\prime}$ end of the 5.8S rDNA (5' - GCTCGTGTGTCGATGAA$\mathrm{GAG}-3^{\prime}$ ), and a specific primer located at $16 \mathrm{bp}$ from the $5^{\prime}$ end of the 28S rDNA (5' - AGGCTTCGGTGCTGGGCT - 3'). Amplified PCR products were purified using a Qiagen
QIAquick Gel Extraction kit (Valencia, CA, USA) and sequenced (Stabvida, Oeiras, Portugal). ITS2 sequences were submitted to GenBank. Sequences were aligned using MAFFT software (available at http://www.ebi.ac.uk/Tools/msa/mafft/). The ITS1 region, a longer variable sequence, was amplified but the sequencing failed. ITS2 sequences of zoogonids 
Diphterostomum sp. (KJ188134.1), Zoogonus rubellus (Olson, 1868) (AJ241804.1), Zoogonus sp. (KF358773.1), Deretrema nahaense Yamaguti, 1942 (KJ188135.1), Lecithostaphylus gibsoni Cribb, Bray \& Barker, 1992 (KJ188133.1), Plectognathotrema kamegaii Cutmore, Miller, Bray \& Cribb, 2014 (KM505036.1) as well as two outgroup species of the family Opecoelidae Macvicaria obovata (Molin, 1859) (JQ694149.1) and Cainocreadium labracis (Dujardin, 1845) (JQ694148.1) were retrieved from GenBank for molecular and phylogenetic studies. Phylogenetic and molecular evolutionary analyses were inferred by both the neighbor-joining (NJ) method using MEGA6 [76] and by Bayesian inference (BI) using BEAST v1.8.0 [23]. To determine the evolution model that gave the best fit to our dataset, the program jModeltest 2.1.1 [18] was employed, with model selection based on the Akaike information criterion (AIC). Results indicated that the general time reversible model with an estimate of gamma distributed among-site rate variation $(\mathrm{GTR}+\mathrm{G}+\mathrm{I})$ was the most appropriate. For NJ analyses, nodal support was estimated from 1000 bootstrap re-samplings. The resulting trees were rooted with the outgroup taxon. Distance matrices ( $p$-distance model, i.e., the percentage of pairwise character differences with pairwise deletion of gaps) were also calculated with MEGA6.

\section{Results}

\section{Taxonomic information}

Subclass: Digenea Carus, 1863

Family: Zoogonidae Odhner, 1902

Genus: Diphterostomum Stossich, 1904

\section{Diphterostomum flavum $\mathbf{n} . \mathbf{s p}$.}

\section{urn:lsid:zoobank.org:act:68BAB7F2-C39F-4692-8AE2-} 168636015221

Definitive host: Pinguipes brasilianus Cuvier (Actinopterygii, Pinguipedidae).

First intermediate host: Buccinanops deformis (Kiener) (Gastropoda, Nassariidae).

Second intermediate hosts: Buccinanops deformis (intrasporocyst), Kinbergonuphis dorsalis (Ehlers) (Polychaeta, Onuphidae) (natural), Platynereis sp. (Polychaeta, Nereididae), and Boccardia proboscidea Hartman (Polychaeta, Spionidae) (experimental).

Type-specimens: Holotype, adult 176 (CNP-Par); paratypes, adult 177 (CNP-Par).

Type-locality: Puerto Lobos (San Matías Gulf) $\left(41^{\circ} 58^{\prime} 50^{\prime \prime} \mathrm{S}, 65^{\circ} 04^{\prime} 05^{\prime \prime} \mathrm{W}\right)$, Patagonian Coast, Southwestern Atlantic Ocean.

Other localities, overall prevalences, infection intensities, and sites of infection: Table 1.

Other specimens deposited: vouchers, sporocyst 6280-6281 (MLP) and 21-23 (CNP-Par), metacercariae 79 (CNP-Par) and 178 (CNP-Par).

GenBank accession numbers: ITS2 sequence of sporocyst (KF358772), metacercaria (MN233043), adult (KF483875), metacercaria of D. brusinae from Portugal (MN263044).
Etymology: The specific name is derived from the Latin "flavum" meaning "yellow" in reference to the color of live adults.

\section{Developmental life cycle stages of Diphterostomum flavum n. sp.}

\section{Adult}

Description: (Figs. 3d-3h-3h and 4). Body elongated and oval, 710 (525-991) long by 222 (160-303) wide, yellow when alive. Posterior region slightly wider and more globular than anterior region. Yellow pigments densely distributed in parenchyma, mainly in older specimens. Tegument densely spiny in forebody; spines become more scattered and smaller toward posterior end (Fig. 4a). Numerous papillae in anterior region (ventral) and surrounding oral sucker (Figs. 4b and 4c). Spines tiny and bifurcated in hindbody (Fig. 4d). Oral sucker terminal, 109 (89-124) in diameter; prepharynx short, 7 (5-10) long; pharynx globular and muscular, 39 (28-54) long by 44 (35-57) wide; esophagus long and straight, 102 (54-142) long, divides into two saccular intestinal caeca, 134 (88-209) long by 49 (34-73) wide, usually terminating anterior to ventral sucker, sometimes slightly overlapping anterior end of ventral sucker. Ventral sucker orange or red, 188 (118-283) in diameter, two pairs of lip-like marginal lobes; sucker ratio 1:1.72 (1:1.321:2.28). Forebody 335 (231-465). Two testes equal and symmetrical, oval to cylindrical, in region of ventral sucker; left testis 104 (92-112) long by 69 (64-82) wide, right testis 93 (83-115) long by 75 (67-95) wide. Cirrus sac large, anterior to ventral sucker, elongated or recurved, containing bipartite seminal vesicle, prostatic pars and long cirrus, 224 (183-285) long by 54 (44-79) wide. Canalicular seminal receptacle posterior to ovary, 64 (56-73) long by 47 (45-51) wide. Genital pore on dorsal, on either left or right margin of body. Ovary dorsal, inter-testicular or slightly pre-testicular close to right testis, 89 (76-112) long by 64 (53-80) wide. Ootype and distal portion of Laurer's canal not seen. Vitelline glands two compacted lobes at testes level, 47 (35-55) long by 35 (33-38) wide. Uterine loops filled with eggs from ventral sucker level to posterior end, never exceed ventral sucker. Eggs elliptical, large, embryonated, 31 (24-41) long by 14 (11-19) wide, membranous capsule. Excretory vesicle spherical, 70 (68-72) long by 74 (74-76) width.

\section{Sporocyst, cercaria, and metacercaria}

Although sporocysts with cercariae and metacercariae of $B$. deformis were described by Durio and Manter [24], here we provide new information about their morphology. Sporocysts (motionless, yellowish and with an elongated body) contain germinal balls, cercariae and/or encysted metacercariae. The majority of sporocysts $(95 \%, n=55)$ contain germinal balls and cercariae in different developing stages. The number of germinal balls and cercariae per sporocyst is $4(1-10)$ and 6 $(2-15)$, respectively. In the few sporocysts $(5 \%, n=3)$ where metacercariae were found, the number of metacercariae per sporocyst is $2(1-5)$. 

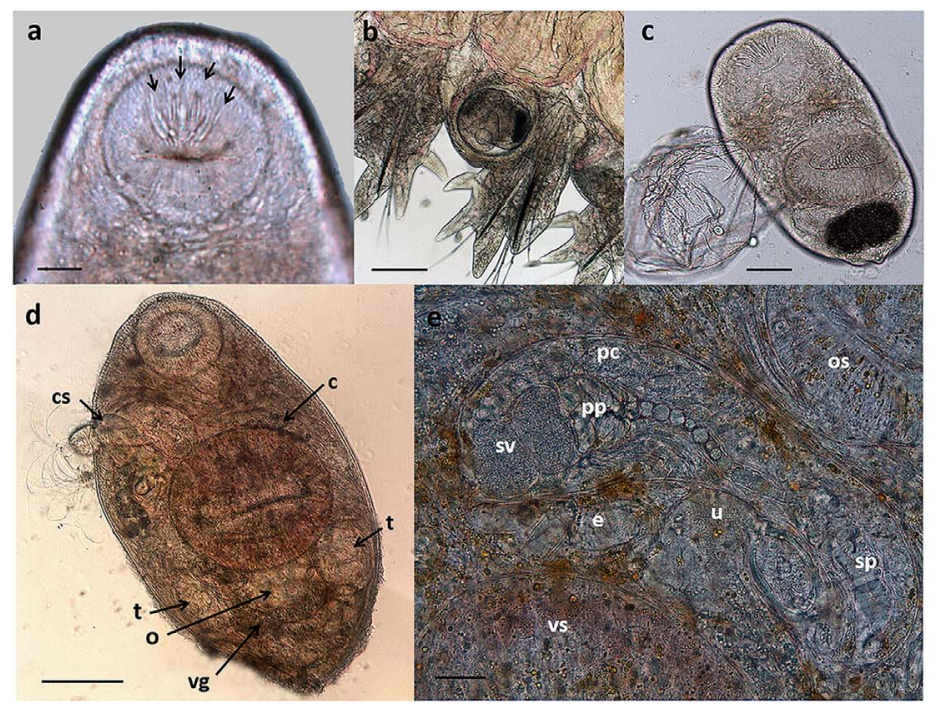

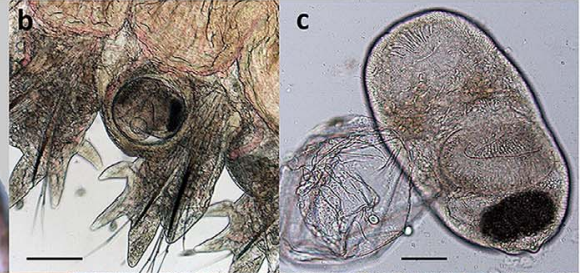

f

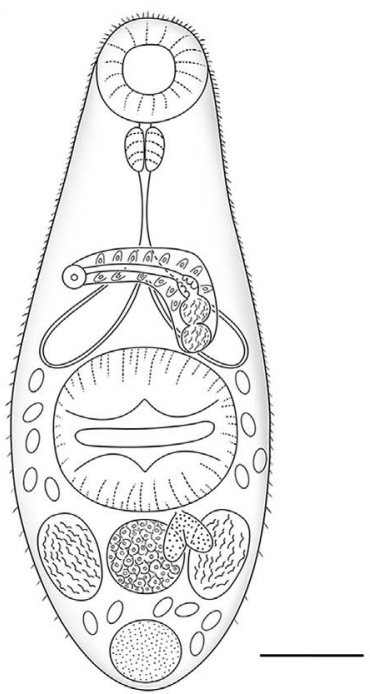

g

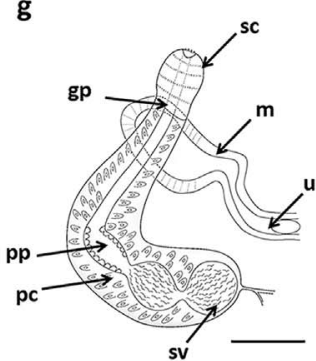

h

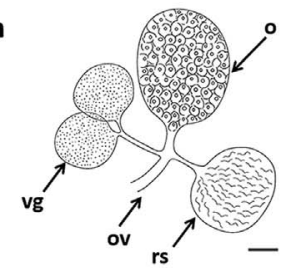

Figure 3. Microphotographs in vivo (a-e) and line drawings (f-h) of Diphterostomum flavum n. sp. (Zoogonidae) parasitizing the fish Pinguipes brasilianus on the Patagonian coast, Argentina: (a) anterior end of cercaria from the gastropod Buccinanops deformis, ducts of penetration glands ending in the oral sucker (arrows), (b) metacercariae naturally encysted in a parapodium of the polychaete Kinbergonuphis dorsalis, (c) metacercariae excysted at laboratory condition, (d) adult from the fish Pinguipes brasilianus with everted cirrus, (e) cirrus sac, (f) adult ventral view, (g) cirrus sac, (h) female genitalia. Abbreviations: c, caeca; cs, cirrus sac; e, egg; gp, genital pore; m, metraterm; o, ovary; ov, oviduct; os, oral sucker; pc, prostatic cells; pp, pars prostatica; rs, seminal receptacle; sc, spinous cirrus; sv, seminal vesicle; t, testis; u, uterus; vg, vitelline glands; vs, vental sucker. Scales: $20 \mu \mathrm{m}(\mathrm{a}, \mathrm{e}, \mathrm{h}), 50 \mu \mathrm{m}$ (c, g), $100 \mu \mathrm{m}$ (b, d, f).
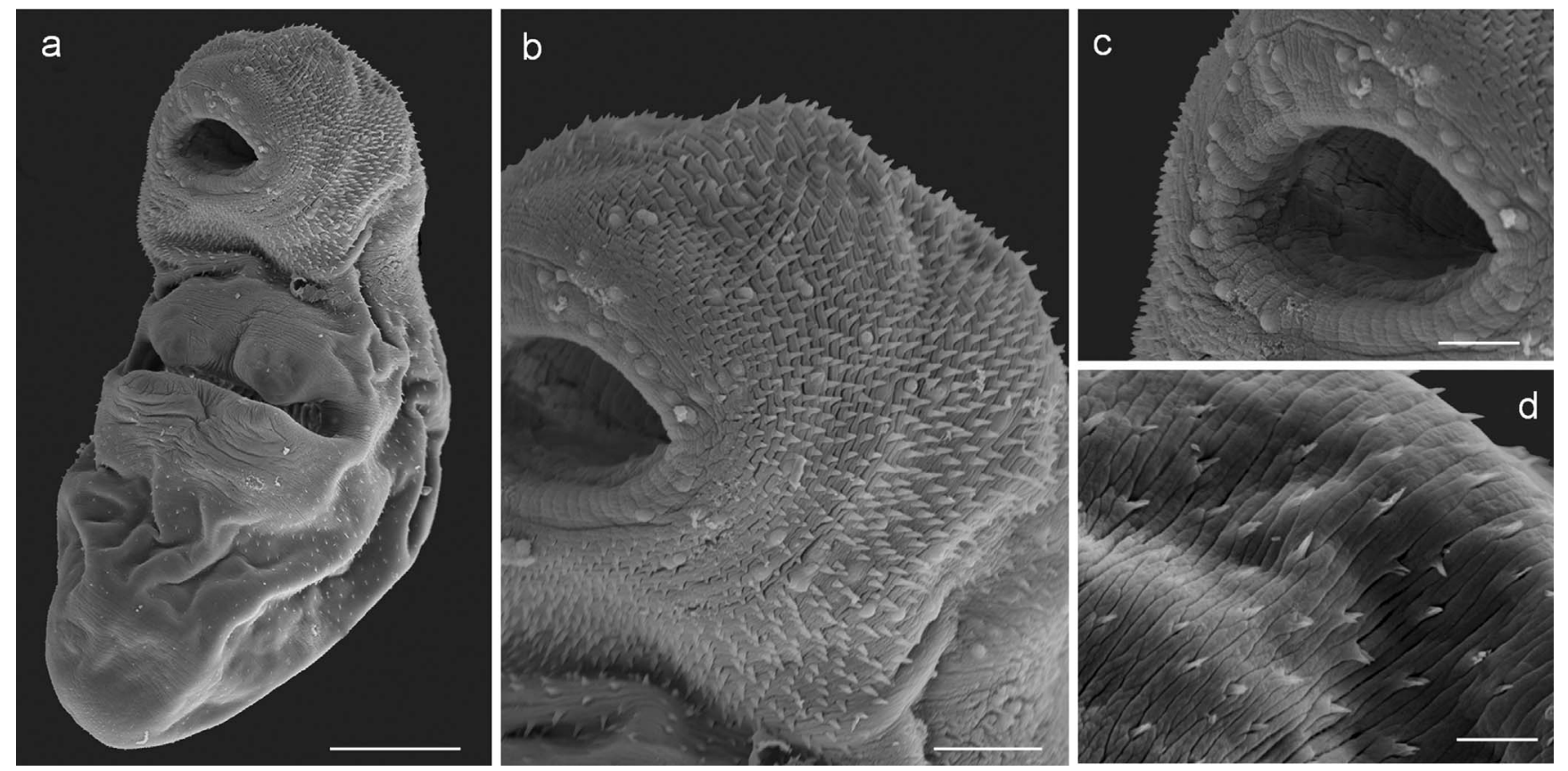

Figure 4. Scanning electron microscope (SEM) photographs of the adult stage of Diphterostomum flavum n. sp. (Zoogonidae) from the Patagonian coast, Argentina. (a) General ventral view. (b) Anterior part of body showing spines and papillae on ventral side. (c) Oral sucker showing papillae. (d) Detail of spines on ventral posterior part of body. Scales: $100 \mu \mathrm{m}$ (a), $50 \mu \mathrm{m}$ (b), $25 \mu \mathrm{m}$ (c), $10 \mu \mathrm{m}$ (d).

The cercaria is microcercous (tailless and with a tiny stylet present in the oral sucker), without eyespots, and bears a prominent ventral sucker with characteristic muscular lips. It possesses short saccular intestinal caeca and at least nine pairs of penetration glands separated in three groups; two groups with three and five pairs of glands opening ventrally at the anterior edge of oral sucker and one pair opening ventrally at the side of oral sucker (Fig. 3a). Developed cercaria has an undeveloped ovary at the left side of the body, a developing testis on each side of the body and an incompletely developed cirrus sac located between the intestinal caeca. The genital pore opens at the left side of the body at the pharyngeal level.

Metacercaria encysted inside sporocyst, spherical, 163 (157-168) diameter with thin wall 6 (5-7) thick. Metacercaria 


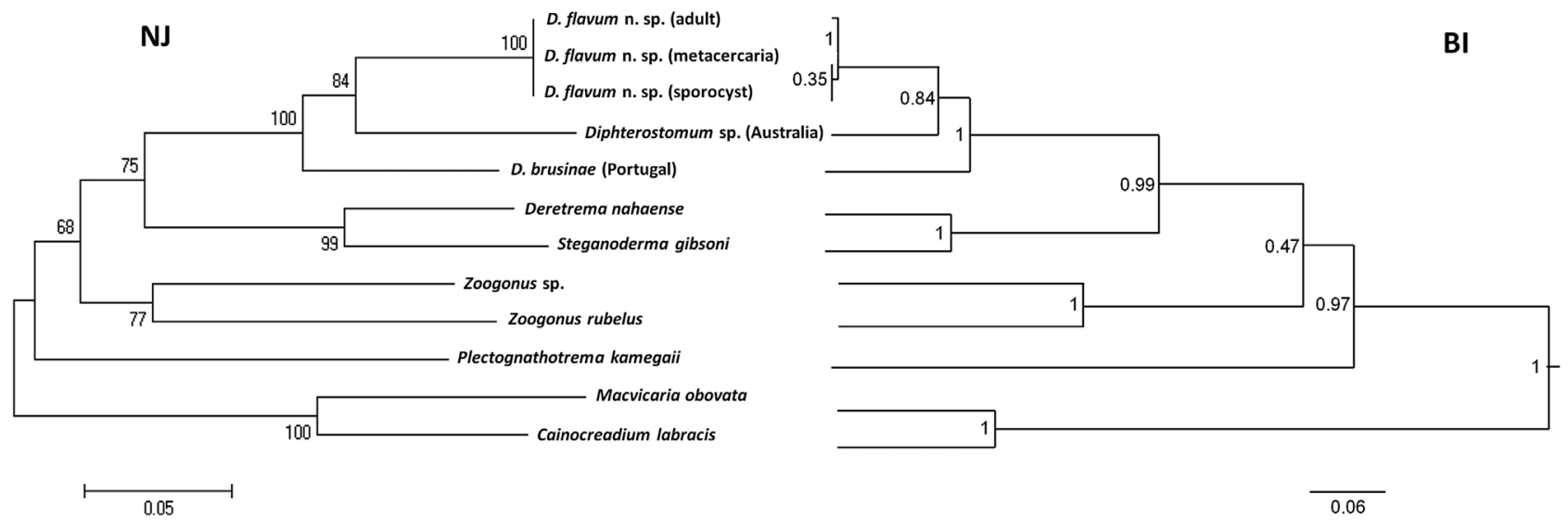

Figure 5. Clustering diagram depicting sequence similarity relationship among Zoogonidae species inferred from ITS2 rDNA. The tree was constructed using the neighbor-joining (NJ) method with pairwise deletion of gaps and Bayesian Inference (BI). NJ nodal numbers represent bootstrap values $(\%, n=1000$ replicates) and BI nodal support is indicated as posterior probabilities. Scale bar indicates substitutions/site.

encysted in polychaete (Fig. 3b) similar, 176 (160-233) diameter and wall 6 (4-7) thick. Excysted metacercaria presents same structures as cercaria but lacks group of three penetration glands opening at anterior edge of oral sucker (Fig. 3c). Body 308 (254-349) long by 135 (92-164) wide; oral sucker 68 (64-71) long by 75 (59-85) wide, ventral sucker 95 (84-103) long by 101 (73-117) wide, and excretory vesicle 79 (62-95) long by 47 (35-53) wide.

\section{Molecular data}

The sequence of the amplified ITS2 fragment of adults of $D$. brusinae from $P$. brasilianus showed a single product of length $476 \mathrm{bp}$. After the sequence analysis, putative $5.8 \mathrm{~S}$ and $28 \mathrm{~S}$ regions were identified through comparisons with identical regions of other digeneans and found to be 73 and 98 nucleotides long, respectively. The sequence encoding for the ITS2 region presented $305 \mathrm{bp}$. No identical sequence was found in GenBank. The sequences encoding the ITS2 region of sporocysts from $B$. deformis and metacercariae from $K$. dorsalis were identical to the adult sequence.

The sequence of the amplified ITS2 fragment of D. brusinae from Portugal showed a single product of length 505 bp. Putative $5.8 \mathrm{~S}$ and $28 \mathrm{~S}$ regions presented 121 and $125 \mathrm{bp}$ respectively and the ITS2 region presented $230 \mathrm{bp}$. The complete fragments (partial 5.8S-ITS2-partial 28S) of D. brusinae from Patagonia and Portugal were compared and these presented differences in $32 \mathrm{bp}$ (distributed all along the sequence) and two gaps.

Neighbor-joining (NJ) and Bayesian inference (BI) analyses resulted in trees with the same topology (Fig. 5). Moreover, both analyses revealed the presence of one clade for the genus Diphterostomum (posterior probability BI: 0.99; bootstrap NJ: 92\%). Diphterostomum flavum n. sp. and D. brusinae present the lowest genetic distance (0.135) (Table 2). The genetic distance is a little higher between D. flavum n. sp. and Diphterostomum sp. (0.138). Genetic distances with species belonging to other genera were higher than 0.250 .

\section{Taxonomic remarks}

The zoogonid adult described here is morphologically indistinguishable from Diphterostomum brusinae first described by Stossich [74]. As Bray [9] pointed out, this species is reported mostly from the Mediterranean and Black Seas, but is also recorded in a wide variety of sites in the Atlantic, Indian, and Pacific Oceans (Fig. 1). At least 34 records of D. brusinae exist around the world, including for six species which were later synonymized (Fig. 1). This species is characterized by having two pairs of lip-like marginal lobes on the ventral sucker, a large cirrus sac anterior to ventral sucker containing a bipartite seminal vesicle and well developed prostatic complex, genital pore sinistral, intertesticular ovary, vitellarium as two compact masses and a uterus filled with large and elliptical eggs [10, 81]. Pina et al. [60] compared some measurements of adults described by Stossich [74], Looss [39], Stafford [73], and Palombi [54, 55] and did not find significant differences. Adults here described have measurements in agreement with these previous works. The sole morphological difference found is in the number of penetration glands of the cercaria. Palombi [54] described two groups without specification of gland number and Pina et al. [60] described three pairs of penetration glands. Cercariae described by Gilardoni et al. [31] were erroneously characterized as having three pairs of penetration glands. New exhaustive morphological study of cercariae allowed recognition of at least nine pairs of penetration glands. Additionally, molecular analysis of ITS2 sequences support the differences between Diphterostomum flavum n. sp., D. brusinae from Portugal and Diphterostomum sp. from Australia (see Molecular data section and Fig. 4). In the Argentinean Sea, three species of Diphterostomum have been recorded: Diphterostomum americanum Manter, 1947 from Puerto Quequén [43], Diphterostomum sp. from North Patagonia [15], and D. brusinae from Buenos Aires Province and North Patagonia [43, 77]; the last of these is identified here as D. flavum n. sp.

\section{Host spectrum and experimental infection}

All the dissections seeking natural infections in the clam (A. petitiana), the crab (O. trimaculatus), and the polychaetes (see species in Table 1) were negative. In the experimental infections, the clam $A$. petitiana was never infected, but the polychaetes from Puerto Madryn were successfully infected. 
Table 2. Pairwise nucleotide sequence comparisons between zoogonid species calculated as the percentage of nucleotide differences (gaps treated as missing data) for the aligned ITS2 sequences $(n=403 \mathrm{bp})$.

\begin{tabular}{lcccccc}
\hline & 1 & 2 & 3 & 4 & 5 & 6 \\
\hline 1. Diphterostomum flavum n. sp. & & & & & & \\
2. Diphterostomum brusinae & 0.135 & & & & & \\
3. Diphterostomum sp. & 0.138 & 0.172 & & & & \\
4. Deretrema nahaense & 0.250 & 0.241 & 0.278 & & & \\
5. Lecithostaphylus gibsoni & 0.286 & 0.256 & 0.288 & 0.127 & & \\
6. Plectognathotrema kamegaii & 0.296 & 0.287 & 0.325 & 0.318 & 0.314 & \\
7. Zoogonus sp. & 0.295 & 0.301 & 0.301 & 0.288 & 0.275 & 0.269 \\
8. Zoogonus rubellus & 0.327 & 0.274 & 0.314 & 0.262 & 0.277 & 0.314 \\
\hline
\end{tabular}

The prevalence of metacercariae in the experimentally infected Boccardia proboscidea was $84 \%(n=20)$ and the mean intensity was $5.76(1-17)$, and in Platynereis sp. was $75 \%(n=4)$ and the mean intensity was 8.33 (3-14). Both overall prevalence $(83.33 \%$ vs. $22.22 \%)$ and mean intensity $(6.15(1-17)$ vs. 1.68 (1-3)) were significantly higher in experimentally than naturally infected polychaetes $K$. dorsalis $(Z=-4.64, p<0.05$; $Z=-7.48, p<0.05)$. The measurements of metacercariae experimentally encysted in polychaetes are similar to those from natural infections: cyst 172 (159-190) diameter, wall 5 (3-9) thick, body 316 (228-379) long by 123 (86-159) wide, oral sucker 61 (48-74) long by 66 (54-78) wide, ventral sucker 83 (66-99) long by $91(80-118)$ wide, and excretory vesicle 63 (46-82) long by 58 (40-73) wide.

\section{Discussion}

This work describes a new species of Diphterostomum, named Diphterostomum flavum n. sp., and its life cycle both naturally and experimentally elucidated by morphological and molecular data. From this study, the existence of cryptic species concealed among forms identified as Diphterostomum brusinae is based on three lines of evidence: (1) a strong morphological character from the cercaria as the number of penetration glands [31], (2) the strict host specificity to the first intermediate host (Fig. 2) [36] and host ecological factors such as feeding habits of the definitive hosts [1], and (3) genetic differences in the ITS2 sequences and genetic distance between species [19].

First, the adult form of $D$. brusinae is characterized by having conspicuous lips on its ventral sucker and, to date, this has been the main diagnostic character considered to recognize the species. Several species that had been described as different from $D$. brusinae in the past were later synonymized with D. brusinae (see Fig. 1) because they lack conspicuous morphological differences and shared the feature of having four lips on the ventral sucker. Because of the lack of conspicuous morphological differences, trematodes have the highest reported level of cryptic diversity [61]. Specifically, most trematodes lack hard parts, especially in their terminal genitalia, which can be of great assistance in species differentiation [61]. Larval stages can be difficult to distinguish morphologically between species $[38,45]$; however, some diagnostic characters of cercariae can be useful including stylet shape, size of suckers, shape of excretory vesicle, and number of penetration glands (e.g., [6, 31, 32]). For D. brusinae, Palombi [54] described two groups of penetration glands in Italian cercariae, Pina et al. [60] described three pairs of glands in Portuguese cercariae, and at least nine pairs of glands separated into three groups are recorded in this study in cercariae from the Southwestern Atlantic Ocean.

Secondly, several studies have demonstrated that the freeswimming miracidial stage that infects the molluscan host shows a strict specificity (e.g., [28, 30, 36, 52, 75]) with the phylogenetic relationships of the hosts driving this specificity $[2,22]$. At the species level, digenean intra-molluscan stages are generally only capable of successful development within a circumscribed set of hosts and it is unusual for a digenean species to complete development in molluscs from more than one family [2]. Some studies have considered sympatric and phylogenetically related snail species. For example, two pulmonate limpets, Siphonaria lessonii Blainville and S. lateralis Gould (Siphonariidae), share a parasite species, the microphallid Maritrema madrynense Diaz \& Cremonte, 2010; these two limpets are ecologically and genetically very similar and can be found together in the same intertidal region from South Patagonia, Argentina [20]. At the same site, Crepipatella dilatata (Lamarck) (Calyptraeidae) inhabits the lower intertidal and subtidal zone and is infected by larvae of a microphallid species very similar to $M$. madrynense but possessing a different stylet and number of penetration glands [31, 32]. Here it is evident that the specificity for the first intermediate host is related to parasite-host co-evolution and morphological differences between larvae.

The cercaria of $D$. brusinae has been recorded in four nassariid and one naticid gastropod species in the Mediterranean, Black Sea, and North of Portugal [21, 54, 55, 60]. Given the geographic distances involved and the overall pattern of host specificity, it is probable that further species of Diphterostomum are present in Europe and on the other continents where it has been recorded.

The degree of specificity of trematode metacercariae to second intermediate hosts is usually lower than that to first intermediate or definitive hosts. The use of a variety of hosts for trophic transmission, increases their chances of being transmitted to the definitive host [33]. Our experimental infections were successful for polychaetes but unsuccessful for a bivalve as second intermediate hosts. Some bivalves such as Chamelea gallina (Linnaeus) (Veneridae), Spisula subtruncata da Costa (Mactridae), and Cerastoderma edule Linnaeus (Cardiidae) have been recorded as second intermediate hosts for D. brusinae from the Black Sea and Portugal on the Northeastern Atlantic coast [21, 60]. In addition, Martorelli et al. [43] experimentally infected the bivalve Limnoperna fortunei (Dunker) (Mytilidae) with cercariae of Diphterostomum 
brusinae from $B$. deformis. In our study, the most common bivalve Ardeamya petitiana, which co-habits with the first intermediate host, $B$. deformis, was never found naturally parasitized. In addition, all attempts at experimental infection failed. This incompatibility could be explained by the feeding habit of A. petitiana which is a deposit feeder that does not expose the mantle when feeding; thus, cercariae cannot enter. Cremonte [17] demonstrated that a gymnophallid cercaria can enter the bivalve Darina solenoides (King) (Mactricidae), but never $A$. petitiana because the former species exposes the mantle border when feeding, allowing the larvae to penetrate.

The molecular differences among Diphterostomum species clearly support the existence of cryptic species. Vilas et al. [78] suggest that a greater than $1 \%$ difference with ITS markers indicates separate species for trematode parasites. The genetic distance between D. flavum n. sp. and D. brusinae from Portugal was $13.1 \%$ and the genetic distance between D. flavum n. sp. and Diphterostomum sp. from Australia was 12.6\%. Despite the limited available sequences of Diphterostomum species, the molecular differentiation is clear and allows species delineation. The rest of the phylogenetic relationships did not agree with others performed with the $28 \mathrm{~S}$ region [71]. Our conclusions are limited to distinguishing among Diphterostomum species, because the ITS2 marker is adequate for this purpose; however, it is not a robust marker for deep-level phylogenetic inference.

In conclusion, the combination of morphology, ecology, and genetics suggests strongly the existence of cryptic species otherwise identifiable as $D$. brusinae, which has been widely recorded around the world. Although molecular analyses are a powerful tool to discriminate among cryptic species, knowledge of digenean life cycles, and the ecology of their hosts adds important biological context to the delineation of such species.

\section{Conflict of interest}

All individual authors declare that they have no conflict of interest (financial, personal, or other).

Acknowledgements. The authors thank E. Bagnato, M. Demetrio, and J. Diaz for help in field and laboratory work, C. Medina for help in molecular studies, J. Groizard (Aluar S.A.) for the SEM photographs, and D. Santrovichi Otero for draws of the life cycles. Financial support was provided by ANPCyT (2016-0653) y Conservation, Food and Health Foundation. FC, CG, JE, and ED are members of the Consejo Nacional de Investigaciones Científicas y Técnicas (CONICET).

\section{References}

1. Adamson ML, Caira JN. 1994. Evolutionary factors influencing the nature of parasite specificity. Parasitology, 109, S85-S95.

2. Adema CM, Loker ES. 1997. Specificity and immunobiology of larval digenean-snail associations. Advances in Trematode Biology, 8, 229-263.

3. Aleshkina LD. 1979. Characteristics of trematode fauna in fish of the south-eastern Atlantic, in VII All-Union Conference on Parasites and Diseases of Fish, Tezisy-Dokladov, Editors. Nauka Leningradskoe Otdelenie: Leningrad. p. 5-6.

4. Amato JFR. 1982. Digenetic trematodes of percoid fishes of Florianópolis, Southern Brasil - Fellodsitomidae, Monascidae,
Diplangidae, Zoogonidae, and Waretrematidae with description of two new species. Revista Brasilera de Biologia, 42, 681-699.

5. Antar R, Gargouri L. 2018. The diversity of teleost fish trematodes in the Bay of Bizerte, Tunisia (Western Mediterranean). Helminthologia, 55, 146-156.

6. Barnett LJ, Miller TL, Cribb TH. 2014. A review of the currently recognised zoogonid cercariae, including the identification and emergence ecology of Cercaria capricornia XI (Digenea: Zoogonidae) from Nassarius olivaceus (Gastropoda: Nassariidae) in Central Queensland, Australia. Folia Parasitologica, 61, 322-330.

7. Bartoli P, Gibson DI, Bray RA. 2005. Digenean species diversity in teleost fish from a nature reserve off Corsica, France (Western Mediterranean), and a comparison with other Mediterranean regions. Journal of Natural History, 39, 47-70.

8. Bellal A, Tazi NAB, Hadjou Z, Boutiba Z. 2016. First records of digenean trematodes of two fishes (Teleostei Sparidae) from the West Algerian coast and comparative study with Tunisian coast (Mediterranean Sea). Biodiversity Journal, 7, 233-240.

9. Bray RA. 1987. A revision of the family Zoogonidae Odhner, 1902 (Platyhelminthes: Digenea): introduction and subfamily Zoogoninae. Systematic Parasitology, 9, 3-28.

10. Bray RA. 2008. Family Zoogonidae Odhner, 1902, in Keys to the Trematoda 3, Bray RA, Gibson DI, Jones A, Editors, Vol. 3. $\mathrm{CAB}$ International and Natural History Museum: London \& UK. p. 605-630.

11. Bray RA, Gibson DI. 1986. The Zoogonidae (Digenea) of fishes from the north-east Atlantic. Bulletin of the British Museum (Natural History) (Zoology Series), 51, 127-206.

12. Bush AO, Lafferty KD, Lotz JM, Shostak AW. 1997. Parasitology meets ecology on its own terms: Margolis et al. revisited. Journal of Parasitology, 83, 575-583.

13. Campos A, Carbonell E. 1994. Parasite community diversity in 2 Mediterranean labrid fishes Symphodus tinca and Labrus merula. Journal of Fish Biology, 44, 409-413.

14. Campos A, Carbonell E, Pellicer M. 1990. Helmintofauna de Symphodus tinca (L.) y Labrus merula (L.) (Pisces: Labridae) del litoral valenciano. I. Trematoda. Revista Ibérica de Parasitología, 50, 37-42.

15. Carballo MJ, Navone GT, Cremonte C. 2011. Parasites of the silversides Odontesthes smitti and Odontesthes nigricans (Pisces: Atherinopsidae) from Argentinean Patagonia. Comparative Parasitology, 78, 95-103.

16. Crawley MJ. 2012. The R book. Hoboken, NJ: John Wiley \& Sons.

17. Cremonte F. 2004. Life cycle and geographic distribution of the gymnophallid Bartolius pierrei (Digenea) on the Patagonian coast, Argentina. Journal of Natural History, 2004(38), 15911604.

18. Darriba D, Taboada GL, Doallo R, Posada D. 2012. jModelTest 2: more models, new heuristics and parallel computing. Nature Methods, 9, 772.

19. Detwiler JT, Bos DH, Minchella DJ. 2010. Revealing the secret lives of cryptic species: examining the phylogenetic relationships of echinostome parasites in North America. Molecular Phylogenetics and Evolution, 55, 611-620.

20. Di Giorgio G, Gilardoni C, Bagnato E, Cremonte F, Ituarte C. 2017. Larval digenean preferences in two sympatric snail species at differing tidal levels off the Atlantic coast of Patagonia. Journal of Helminthology, 91, 696-702.

21. Dolgikh AV, Naidenova NN. 1967. Contribution to the study of helminth parasites of Diplodus annularis. Scientific Reports of the Superior School Biological Sciences, 11, 13-16. 
22. Donald KM, Kennedy M, Poulin R, Spencer HG. 2004. Host specificity and molecular phylogeny of larval Digenea isolated from New Zealand and Australian topshells (Gastropoda: Trochidae). International Journal for Parasitology, 34, 557-568.

23. Drummond AJ, Rambaut A, Suchard MA. 2002-2013. BEAST v1.8.0. Bayesian evolutionary analysis sampling trees. Auckland: Department of Computer Science, University of Auckland.

24. Durio WO, Manter HW. 1968. Some digenetic trematodes of marine fishes of New Caledonia. Part I. Bucephalidae, Monorchiidae, and some smaller families. Proceedings of the Helminthological Society of Washington, 35, 143-153.

25. Fischthal JH. 1980. Some digenetic trematodes of marine fishes from Israel's Mediterranean coast and their zoogeography, especially those from Red Sea immigrant fishes. Zoologica Scripta, 9, 11-23.

26. Francisco CJ, Almeida A, Castro AM, Pina S, Russell-Pinto F, Rodrigues P, Santos MJ. 2011. Morphological and molecular analysis of metacercariae of Diphtherostomum [sic] brusinae (Stossich, 1888) Stossich, 1903 from a new bivalve host Mytilus galloprovincialis. Journal of Helminthology, 85, 179-184.

27. Gaevskaya AV. 1996. New records of trematodes from eastern Atlantic fishes. Parazitologiya, 30, 504-509.

28. Galaktionov KV, Dobrovolskij AA. 2003. The biology and evolution of trematodes. The Netherlands: Kluwer.

29. Georgieva S, Selbach C, Faltýnková A, Soldánová M, Sures B, Skírnisson K, Kostadinova A. 2013. New cryptic species of the "revolutum" group of Echinostoma (Digenea: Echinostomatidae) revealed by molecular and morphological data. Parasites \& Vectors, 6, 64 .

30. Gibson DI, Bray RA. 1994. The evolutionary expansion and host-parasite relationships of the Digenea. International Journal for Parasitology, 24, 1213-1226.

31. Gilardoni C, Etchegoin JA, Diaz JI, Ituarte C, Cremonte C. 2011. A survey of larval digeneans in the commonest intertidal snails from Northern Patagonian coast, Argentina. Acta Parasitologica, 56, 163-179.

32. Gilardoni C, Di Giorgio G, Bagnato E, Cremonte F. 2019. Survey of trematodes in intertidal snails from Patagonia, Argentina: new larval forms and diversity assessment. Journal of Helminthology, 93, 342-351.

33. Jousson O, Bartoli P, Pawlowski J. 2000. Cryptic speciation among intestinal parasites (Trematoda: Digenea) infecting sympatric host fishes (Sparidae). Journal of Evolutionary Biology, 13, 778-785.

34. Kohn A, Fernandez BMM, Cohen SC. 2007. South American Trematodes parasites of fishes. Rio de Janeiro: Ministério da Saúde, FIOCRUZ, Fundaçao Oswaldo Cruz.

35. Korotaeva VD. 1975. Contribution to the fauna of helminths and parasitic crustaceans of marine commercial fishes of the Australian and New Zealand waters. Trudy Biologo-pochvennogo Instituta Novaya Seriya, 26, 46-60. (in Russian).

36. Kostadinova A, Gibson DI. 2000. The systematics of the echinostomes, in Echinostomes as experimental models for biological research, Fried B, Graczy TK, Editor. Kluwer Academic Publishers: The Netherlands. p. 31-57.

37. Kostadinova A, Herniou GA, Barrett J, Littlewood DTL. 2003. Phylogenetic relationships of Echinostoma Rudolphi, 1809 (Digenea: Echinostomatidae) and related genera reassessed via DNA and morphological analyses. Systematic Parasitology, 54, 159-176.

38. Leung TLF, Keeney DB, Poulin R. 2009. Cryptic species complexes in manipulative echinostomatid trematodes: when two become six. Parasitology, 136, 241-252.

39. Looss A. 1901. Ueber einige Distomen der Labriden des Triester Hafens. Centralblatt für Bakteriologie, Parasitenkunde Infektionskrankheiten, 29, 398-405.
40. Lozano C, Ubeda JM, De Rojas M, Ariza G, Guevara DC. 2001. Estudio de digénidos de peces marinos del sur de la Península Ibérica. Revista Ibérica de Parasitología, 61, 103-116.

41. Machida M, Kamegai S, Kuramochi T. 2006. Zoogonidae (Trematoda, Digenea) from fishes of Japanese waters. Bulletin of the National Science Museum, Tokyo. Series A. Zoology, 32, 95-104.

42. Malenke JR, Johnson KP, Clayton DH. 2009. Host specialization differentiates cryptic species of feather-feeding lice. Evolution, 63, 1427-1438.

43. Martorelli SR, Montes MM, Marcotegui PS, Alda MDP. 2014. Primer registro de Diphterostomum brusinae (Digenea, Zoogonidae) parasitando a la corvina Micropogonias furnieri con datos sobre su ciclo biológico. Revista Argentina de Parasitología, 2, 22-27.

44. McNamara MKA, Miller TL, Cribb TH. 2014. Evidence for extensive cryptic speciation in trematodes of butterflyfishes (Chaetodontidae) of the tropical Indo-West Pacific. International Journal for Parasitology, 44, 37-48.

45. Miura O, Kuris AM, Torchin ME, Hechinger RF, Dunham EJ, Chiba S. 2005. Molecular-genetic analyses reveal cryptic species of trematodes in the intertidal gastropod, Batillaria cumingi (Crosse). International Journal for Parasitology, 35, 793-801.

46. Morgan JAT, Blair D. 1998. Mitochondrial ND1 gene sequences used to identify echinostome isolates from Australia and New Zealand. International Journal for Parasitology, 28, 493-502.

47. Muñoz G, Díaz PE. 2015. Checklist of parasites of labrid fishes (Pisces: Labridae). Santiago de Chile: Departamento de Derechos Intelectuales.

48. Nahhas FM, Cable RM. 1964. Digenetic and aspidogastrid trematodes from marine fishes of Curaçao and Jamaica. Tulanes Studies in Zoology, 11, 169-227.

49. Nahhas FM, Powell EC. 1971. Digenetic trematodes of marine fishes from the Floridian northern Gulf of Mexico. Tulane Studies in Zoology and Botany, 17, 1-9.

50. Nahhas FM, Nasser H, Tam J. 2004. Digenetic trematodes of marine fishes from Suva, Fiji: families: Acanthocolpidae, Lepocreadiidae, Bivesiculidae, Zoogonidae, Monorchiidae and description of a new species. Rivista di Parassitologia, 21, 33-48.

51. Naidenova NN. 1974. Parasite fauna of the family of Gobies of the Black and Azov Sea, Naukova Dumka: Kiev. p. 182 (in Russian).

52. Nunez PE, De Jong-Brink M. 1997. The suppressive excretorysecretary product of Trichobilharzia ocellata: a possible factor for determining compatibility in parasite-host interactions. Parasitology, 115, 193-203.

53. Oguz MC, Bray RA. 2006. Digenetic trematodes of some teleost fish off the Mudanya Coast (Sea of Marmara, Turkey). Helminthologia, 43, 161-167.

54. Palombi A. 1930. Il ciclo biologico di Diphterostomum brusinae Stossich (Trematode digenetico: fam. Zoogonidae Odhner). Considerazioni sui cicli evolutivi dell especie affini e dei trematodi in generale. Pubblicazioni della Stazione zoologica di Napoli, 10, 111-149.

55. Palombi A. 1934. Gli stadi larvali dei trematodi del Golfo de Napoli, $1^{\circ}$ Contributo allo studio della morfologia, biologia, e sistematica delle cercarie marine. Pubblicazioni Della Stazione Zoologica di Napoli, 14, 51-94.

56. Papoutsoglou SE. 1976. Metazoan parasites of fishes from Saronicos Gulf Athens - Greece. Thalassographica, 1, 69-102.

57. Parukhin AM. 1976. Parasitic worms of food fishes of the southern seas. Kiev: Naukova Dumka. p. 183. (in Russian).

58. Parukhin AM. 1978. On studies in trematodofauna of the Indian and Atlantic Ocean fishes. Biologiya Morya, Kiev, 45, 90-99. (in Russian). 
59. Pérez-Ponce de León G, García-Prieto L, Mendoza-Garfias B. 2007. Trematode parasites (Platyhelminthes) of wildlife vertebrates in Mexico. Zootaxa, 1534, 1-247.

60. Pina S, Tajdari J, Russell-Pinto F, Rodrigues P. 2009. Morphological and molecular studies on life cycle stages of Diphtherostomum brusinae (Digenea: Zoogonidae) from northern Portugal. Journal of Helminthology, 83, 321-331.

61. Poulin R. 2010. Uneven distribution of cryptic diversity among higher taxa of parasitic worms. Biology Letters, 7, 241-244.

62. Prévot G. 1966. Sur deux Trématodes larvaires d'Antedon mediterranea Lmk. (Echinoderme): Metacercaria sp. (Monorchiidae Odhner, 1911) et métacercaire de Diphterostomum brusinae Stoss., 1904 (Zoogonidae Odhner, 1911). Annales de Parasitologie Humaine et Comparée, 41, 233-242.

63. Radujkovic B, Sundic D. 2014. Parasitic flatworms (Platyhelminthes: Monogenea, Digenea, Cestoda) of fishes from the Adriatic Sea. Natura Montenegrina, 13, 7-280.

64. Radujkovic BM, Orecchia P, Paggi L. 1989. Parasites of marine fishes from Montenegro: digeneans. Acta Adriatica, 30, 137-187.

65. Saad-Fares A, Combes C. 1992. Abundance/host size relationship in a fish trematode community. Journal of Helminthology, 66, 187-192.

66. Sasal P, Niquil N, Bartoli P. 1999. Community structure of digenean parasites of sparid and labrid fishes of the Mediterranean Sea: a new approach. Parasitology, 119, 635-648.

67. Scheifler M, Ruiz-Rodríguez M, Sanchez-Brosseau S, Magnanou E, Suzuki MT, West N, Duperron S, Desdevises Y. 2019. Characterization of ecto-and endoparasite communities of wild Mediterranean teleosts by a metabarcoding approach. Plos One, 14, e0221475.

68. Schulze W. 1970. Trematodes digeneos del intestino del Besugo colorado (Pagrus pagrus L. Familia Sparidae) de las aguas costeras argentinas. Neotrópica, 16, 58-64.

69. Sey O, Nahhas FM, Uch S, Vang C. 2003. Digenetic trematodes from marine fishes off the coast of Kuwait, Arabian Gulf: Fellodistomidae and some smaller families, new host and geographic records. Acta Zoologica Academiae Scientiarum Hungaricae, 49, 179-200.

70. Siegel S, Castellan NJ. 1988. Nonparametric statistics for the behavioural sciences. New York: McGraw-Hill.
71. Sokolov S, Gordeev I, Lebedeva D. 2016. Redescription of Proctophantastes gillissi (Overstreet et Pritchard, 1977) (Trematoda: Zoogonidae) with discussion on the systematic position of the genus Proctophantastes Odhner, 1911. Acta Parasitologica, 61, 529-536.

72. Sproston NG. 1939. Notes sur la faune parasitaire des poissons à Roscoff. Travaux de la Station biologique de Roscoff, 16, 33-58.

73. Stafford J. 1905. Trematodes from Canadian vertebrates. Zoologischer Anzeiger, 28, 681-694.

74. Stossich M. 1888. Appendice al mio lavoro "I distomi dei pesci marini e d'acqua dolce". Programma del Ginnasio Comunale Superiore di Trieste, 35, 95-105.

75. Stunžènas V, Petkevičiūtė R, Poddubnaya LG, Stanevičiūtė G, Zhokhov AE. 2017. Host specificity, molecular phylogeny and morphological differences of Phyllodistomum pseudofolium Nybelin, 1926 and Phyllodistomum angulatum Linstow, 1907 (Trematoda: Gorgoderidae) with notes on Eurasian ruffe as final host for Phyllodistomum spp. Parasites and Vectors, 10, 286.

76. Tamura K, Stecher G, Peterson D, Filipski A, Kumar S. 2013. Mega6: molecular evolutionary genetics analysis version 6.0. Molecular Biology and Evolution, 30, 2725-2729.

77. Timi JT, Lanfranchi AL, Etchegoin JA, Cremonte F. 2008. Parasites of the Brazilian sandperch Pinguipes brasilianus Cuvier: a tool for stock discrimination in the Argentine Sea. Journal of Fish Biology, 72, 1332-1342.

78. Vilas R, Criscione CD, Blouin MS. 2005. A comparison between mitochondrial DNA and the ribosomal internal transcribed regions in prospecting for cryptic species of platyhelminth parasites. Parasitology, 131, 839-846.

79. WoRMS Editorial Board. 2019. World Register of Marine Species. Available from http://www.marinespecies.org at VLIZ. Accessed 25-07-2019. doi: 10.14284/170. 69

80. Yamaguti S. 1934. Studies on the helminth fauna of Japan. Part 2. Trematodes of fishes, I. Japanese Journal of Zoology, 5, 249-541.

81. Yamaguti S. 1971. Synopsis of digenetic trematodes of vertebrates - digenea of fishes. Tokyo: Keigaku Publishing Co.

82. Yamaguti S. 1975. A synoptical review of life histories of digenetic trematodes of vertebrates with special reference to the morphology of their larval forms. Tokyo: Keigaku Publishing Co.

Cite this article as: Gilardoni C, Etchegoin J, Cribb T, Pina S, Rodrigues P, Diez ME \& Cremonte F. 2020. Cryptic speciation of the zoogonid digenean Diphterostomum flavum n. sp. demonstrated by morphological and molecular data. Parasite 27, 44.

Reviews, articles and short notes may be submitted. Fields include, but are not limited to: general, medical and veterinary parasitology; morphology, including ultrastructure; parasite systematics, including entomology, acarology, helminthology and protistology, and molecular analyses; molecular biology and biochemistry; immunology of parasitic diseases; host-parasite relationships; ecology and life history of parasites; epidemiology; therapeutics; new diagnostic tools.

All papers in Parasite are published in English. Manuscripts should have a broad interest and must not have been published or submitted elsewhere. No limit is imposed on the length of manuscripts.

Parasite (open-access) continues Parasite (print and online editions, 1994-2012) and Annales de Parasitologie Humaine et Comparée (1923-1993) and is the official journal of the Société Française de Parasitologie. 